\title{
PlanNed DifFERENCES: Argentina's UNIVERSAL CHILD ALLOWANCE FROM A HUMAN RIGHTS PERSPECTIVE
}

DIFERENCIAS PLANEADAS: LA ASIGNACIÓN UNIVERSAL POR HIJO EN ARGENTINA DESDE UNA PERSPECTIVA DE DERECHOS HUMANOS

Horacio Javier Etchichury*

Abstract: This article intends to analyze Universal Child Allowance (UCA) - a large-scale conditional cash transfer (CCT) program in Argentina - from a human rights and constitutional perspective. Conditions required in the UCA system-which covers informal and unemployed workers-are compared to those established in family allowances, the contributory program created for registered workers. These differences in treatment are analyzed in connection with the right to equal treatment, taking into account applicable legal materials, including caselaw and theoretical contributions. After describing CCT programs in general and the specific features of UCA, and outlining Argentina's constitutional and human rights framework, the article describes the specific conditions - maximum income, nationality, maximum number of covered children-applied only to informal and unregistered workers included in the UCA program. Compared to family allowances beneficiaries, workers under UCA have a much lower maximum wage limit to be eligible, and their children must fulfill nationality or legal residence requirements not applicable under the family allowances system. UCA covers only up to five children per family, while family allowances are paid to every child in formal workers' families, with no restrictions. The article concludes that these planned differences in treatment

\footnotetext{
* LL. M., Yale Law School. Doctor in Law, Universidad Nacional de Córdoba (National University of Córdoba), Argentina. Adjunct Faculty, Law School, National University of Córdoba. Adjunct Researcher, CONICET (Argentina's National Council of Scientific and Technological Research). Director, Grupo de Investigación en Derechos Sociales (GIDES). etchichury74@gmail.com
} 
are not admissible under Argentina's human rights obligations and constitutional setting. The article also advocates a human rights-based design for social policies, in order to ensure consistency with Argentina's Constitution and international obligations.

Keywords: Social Rights, Universal Child Allowance, Equality, Children's Rights, Social Policy

Resumen: Este artículo analiza la Asignación Universal por Hijo (AUH) - un programa argentino a gran escala de transferencias monetarias condicionadas (TMC) — desde un punto de vista constitucional y de derechos humanos. Se comparan las condiciones en el sistema de la AUH - que cubre a trabajadores informales o desempleados-con aquéllas requeridas en el programa contributivo de Asignaciones Familiares (AF) para empleados registrados. Se analizan estas diferencias en relación con el derecho a la igualdad de trato, considerando jurisprudencia y contribuciones teóricas. Tras describir las TMC en general, las características de la AUH y el marco constitucional y de derechos humanos en Argentina, se analizan las condiciones específicas —máximo posible de ingreso, nacionalidad, número máximo de niños cubiertos-aplicadas a quienes perciben la AUH. En contraste con los beneficiarios de AF, los trabajadores abarcados por la AUH tienen un umbral mucho más bajo en cuanto al máximo sueldo admisible y sus hijos deben cumplir requisitos de nacionalidad o de residencia legal no exigidos en el caso de AF. La AUH cubre hasta cinco niños por familia, mientras que las AF se abonan a cada hijo de empleados formales, sin restricciones. El artículo concluye que estas diferencias planificadas de tratamiento no son admisibles frente a la Constitución argentina y a las obligaciones en materia de derechos humanos. El artículo también aboga por la adopción de un diseño de politicas sociales basado en derechos, a fin de asegurar la coherencia con la Constitución y las obligaciones internacionales de Argentina.

Palabras clave: Derechos sociales, asignación universal por hijo, igualdad, derechos del niño, política social

Sumario. I. Introduction. II. CCT programs in latin america. III. Uca: a cct program in argentina. IV. Assesing UCA from a new perspective: human rights, constitutional rights. V. Human rights questions, constitutional problems. VI. Conditioned rights. VII. A question of equality. VII.1. Maximum income. VII.2. Nationality. VII.3. Required documents. VII.4. Number of included children. VIII. Conclusions: policy implications of constitutional review. References. 


\section{INTRODUCTION}

In this article, I take a human rights prospective to analyze the design of the Universal Child Allowance (hereinafter "UCA"; Asignación Universal por Hijo, in Spanish), a large-scale noncontributory conditional cash transfers program in Argentina. First, I describe Conditional Cash Transfers (CCT) as an increasingly embraced policy option in Latin America. Then I characterize UCA and its differences with the corresponding contributory program, family allowances (Asignaciones Familiares, in Spanish). I analyze UCA design from a human rights and constitutional perspective to argue unjustified differences between children contradict the right to equal treatment and other relevant rights. Finally, I suggest human and constitutional rights should have a decisive role in Argentina's policy design process in order to avoid these unacceptable planned differences.

\section{CCT PROGRAMS IN LATIN AMERICA}

In the final decades of the 20th century, poverty reduction became a significant item in the global policy agenda and "the poor" emerged as a defined group for policy purposes (Morais de Sá e Silva, 2017; Lavinas, 2015). Debates arose about different approaches on poverty and its causes and effects, and on the most suitable strategies to improve the lives of the poor. Influential international institutions like the World Bank joined this effort. In 1989 then-President Lewis Preston insisted in taking poverty reduction as the Bank's central concern. A two-part strategy can be found in the 1990 World Development Report, the Bank's flagship publication. First, growth would be based in labor-intensive activities. Second, States should grant a comprehensive provision of basic health and education, while establishing appropriate safety nets. Social lending increased, as "market liberalization" programs remained the overriding policy framework (Abouharb \& Cingranelli, 2007, p. 63; Kanbur \& Vines, 2000, pp. 101-103), in spite of controversial results. After structural adjustment programs were put in practice, growth rates kept negative or extremely low. Health care, education and infrastructure investment diminished, while external debt continuously increased (Abouharb \& Cingranelli, 2007, pp. 3, 9-10, 25, 63). As early as in 1990, a World Bank technical publication admitted that, after nine years of adjustment policies, few clear signs of success could be seen (Ribe et al., 1990). 
In the continuous search for instruments to reduce poverty, CCT programs appear to be a promising alternative. Access to welfare payments is subject to specific actions by those who receive the money, usually poverty-stricken families. Under these public programs, for example, they must ensure their children attend school and get vaccinations, among other health-related requirements. This set of conditions may improve their condition, by breaking «the intergenerational cycle of poverty» (Morais de Sá e Silva, 2017, p. 3; Rabinovich \& Diepeveen, 2015). A World Bank's technical publication defines these conditions as «prespecified investments in the human capital [of children]» (Fiszbein et al., 2009), in line with the previously described 1990s strategy.

CCT programs have multiplied all over the world in the past few years: 45 programs in 40 countries were in place in 2016. The World Bank pioneered this approach in 1994, by funding Bangladesh's Female Secondary School Assistance Program (Morais de Sá e Silva, 2017, pp. 3, 14-16). Statistical studies on Latin American countries that implement CCT programs show that poverty levels in those countries would have been $13 \%$ higher had the programs not been put in place (Stampini \& Tornarolli, 2012, p. 11). CCT programs "seem to differentially favor disadvantaged groups" in Latin America, though they do not eliminate inequality of opportunitythe impact of elements beyond individual control (Ham, 2014, p. 172). Since the early 2000s, economic growth in the region made more fiscal resources available for CCT programs (Stampini \& Tornarolli, 2012, p. 12). Political feasibility, in turn, is another important concern: Fiszbein et al. (2009) highlight that inserting conditions makes it easier to gather political support for these programs. Transfers subject to certain requirements appear to be more acceptable for those social sectors who do not receive these payments (Skocpol, 1991). CCT programs seem to demand beneficiaries to "do something" in order to obtain the money. They are required to "earn" their access to social security. A former World Bank senior manager, however, has expressed his concern about the "rush" to create these programs, since they focus on the demand side while some countries face challenges on the provision of public services such as education and healthcare (Ravallion, 2016, pp. 88-89).

Generally speaking, these programs have a less-than-universal coverage (Stampini \& Tornarolli, 2012), under a targeted-benefits scheme favored by the IMF, the World Bank and the OECD (Morissens, 2018, p. 361; Ravallion, 2016, p. 88). However, these programs show various forms (Ceballos \& Lautier, 2013). Some of them claim to be universal or, at least, almost universal, as I discuss in other sections. 
Although different belief systems can offer compelling justifications for CCT, human capital theories appear to be a central foundation for these proposals (Morais de Sá e Silva, 2017, pp. 6, 171). CCT programs assume poverty is caused by a lack of human capital, in other words, insufficient education, or deficient healthcare, just to mention two examples. Cash transfers would be the key to build the lacking human capital. Using transfers as an incentive, these programs intend to modify families' behavior and choices, leading them to engage in a rational cost-benefit analysis (Valencia Lomelí, 2008). There is no room, under such a policy, to discuss the fairness or unfairness of existing economic structures, where poverty grows. To reform such structures, if found unfair, would be a lot more difficult than setting up a CCT program. Such a system looks comfortably appealing in the eyes of policymakers. It can thrive without risking confrontations with powerful market forces, who remain untouched. Ceballos and Lautier (2013) argue that CCT programs offer a suitable way to depoliticize debates around poverty. Lo Vuolo (2012, p. 157), in turn, highlights that these schemes put in place "new contractual figures" between the State and selected individuals through the use of fiscal resources: several predefined activities appear as conditions (or "co-responsibilities") to receive a certain amount of public money. Such a contractual design may discourage a collective, deeper, or more political approach to social issues of inclusion and distribution. Feminist critics, such as Pautassi (2017), highlight the absence of a gender focus in most CCT programs.

Latin American countries have put in place various cash transfer programs, usually centered in children (Arza, 2018). Mexico's Progresa, launched in 1997, is usually described as the first nation-wide program in the region. Renamed Oportunidades in 2002, it is known as Prospera since 2014. Bolsa Família ${ }^{1}$ was established in Brazil with World Bank assistance (Morais de Sá e Silva, 2017, pp. 125-127). Under a different vision, Chile includes only "the most vulnerable groups" in its Ingreso Ético Familiar program (previously known as Chile Solidario), aimed at "overcoming extreme poverty" 2 . Direct participation of international financial institutions in these cash transfer systems in Latin America has been steadily increasing (Valencia Lomelí, 2008).

These programs do not incorporate families into preexisting systems: expansion is achieved through the creation of separate benefits for poor, unregistered or unemployed workers, in a "segmented expansion" process.

\footnotetext{
${ }^{1}$ See the official site, at: http://www.mds.gov.br/bolsafamilia (accessed August $8^{\text {th }}, 2018$ ).

${ }^{2}$ See the official site, at: http://www.ingresoetico.gob.cl/que-es-ief/ (accessed August $8^{\text {th }}$, 2018).
} 
A residual logic predominates-programs cover selected workers and families excluded from the official labor market. CCT programs are «income-tested, conditioned, and offer small amounts of cash» (Arza, 2018, pp. 60,69). They target those who are poor or at risk of poverty or extreme deprivation; allowances are not intended to replace living wages but to prevent beneficiaries and their families from worsening their situation. Generally, these programs are not framed as rights or constitutional guarantees (Morais de Sá e Silva, 2017), but only as statutory benefits that can be modified through ordinary legislation, or even through Executive decrees. At the same time, noncompliance usually implies the loss or suspension of benefits. Lo Vuolo (2012, p. 160) describes these schemes as "punitive" since they include sanctions against beneficiaries who fail to abide by required conditions.

\section{UCA: A CCT PROGRAM IN ARGENTINA}

Argentina's UCA is one of these non-contributory CCT programs. It grants allowances to children of unemployed and informal workers, as long as families comply with certain conditionalities: children must attend school and go through regular health check-ups. UCA is officially presented as an expansion of the family allowances system established in 1957 for registered workers.

Through Necessity and Urgency Decree ${ }^{3}$ 1602/2009, President Cristina Fernández created the UCA in October 2009. The UCA is a monthly cash payment to one of the parents (mothers have priority) for each child under 18 years old, up to a maximum of 5 children per family. Payments are subject to compliance of healthcare and school attendance conditions. 80\% of the monthly benefit is regularly paid to the designated parent; the remaining $20 \%$ can be collected at the end of the year after handing in certificates to prove conditionalities were met. Eligible parents must be unemployed, or must be unregistered workers earning less than the official minimum wage (Arza, 2018; Bertranou and Maurizio, 2012; Arcidiácono, 2016; Pribble, 2013). UCA now covers almost 4 million children; Brazil's Bolsa Familia includes 12.7 million households, while Chile's CCT program covers 1.3 million children (Arza, 2018, p. 63). As of June 2018,

\footnotetext{
${ }^{3}$ According to art. 99.3 of Argentina's Constitution, this kind of Decrees have the same effect and rank as a statute passed by Congress. Necessity and Urgency Decrees can be issued by the President «[o]nly when due to exceptional circumstances the ordinary procedures foreseen by this Constitution for the enactment of laws are impossible to be followed».
} 
the monthly payment amounts to AR $\$$ (Argentinian pesos) $1,578^{4}$ (approximately 56 US dollars, at the current official exchange rate). As in other countries, the World Bank contributed to consolidate UCA through a 480 million US dollars loan in 2011 (cfr. World Bank, 2011b), a complement of a previous 2009 loan aimed at improving social protection systems. The Bank considers UCA as an important step in the process of closing previous social protection schemes, centered in the Heads of Households program, which was an emergency response to the 2001 crisis (World Bank, 2011).

UCA, as a non-contributory cash transfer system, appears to be an extension of the pre-existing contributory family allowances scheme. Family allowances are paid only to registered workers whose combined family income is less than AR \$ 83,917 (around 3,000 US dollars at August 2018 official exchange rate $)^{5}$. Registered employees whose combined family income is more than AR \$24,491 (approximately 875 US dollars) and less than AR $\$ 83,917$ receive a reduced amount of family allowances. In 2016, self-employed registered workers at the lowest income bracket were included in the family allowances system (cfr. Presidential Decree 593/2016). Almost 5 million children are currently covered by family allowances (Arza, 2018).

UCA amount is equal to the highest family allowances value (in other words, the one paid to registered workers whose combined family income is below AR\$ 24,492). Family allowances and UCA figures are regularly adjusted through the pension index ${ }^{6}$. This underscores a sense of equality between the two separate systems, both funded by the social security budget. ANSES, the national social security agency (Spanish: Administración Nacional de la Seguridad Social), administers both benefits. Access to both systems is automatic.

In spite of all the similarities between family allowances and UCA, both programs differ. As I show below, conditions, payment schedule, and entry requirements to receive the allowance are not the same for registered and unregistered workers. These differences deserve a specific, rights-based scrutiny. In the next section, I offer such an analysis.

4 Data available at the official site: http://www.anses.gob.ar/informacion/montos-deasignacion-universal-por-hijo-y-por-embarazo-para-proteccion-social/ (accessed August $\left.8^{\text {th }}, 2018\right)$.

5 Figures established by Decree 702/2018. These figures are regularly modified by Presidential Decree, according to average wage increases. Families are also excluded from the family allowances system if one of its members earns more than AR $\$ 41,959$ (approximately 1,500 US dollars) regardless of the combined income.

${ }^{6}$ See Law 27.160, approved in July 2015. Pension index was reformed by Law 27.426 in December 2017. 


\section{ASSESING UCA FROM A NEW PERSPECTIVE: HUMAN RIGHTS, CONSTITUTIONAL RIGHTS}

Adoption of UCA in Argentina spurred a series of studies to assess its effects on poverty reduction, school attendance, and other social relevant issues. Available sociological research shows positive effects, such as the reduction of indigence levels among children (Bertranou and Maurizio, 2012) or the growing rate of schooling in families that receive these payments. A group of public universities carried on an early appraisal on how UCA impacted on education (Ministerio de Educación, 2011). A later study, based on official data, concluded that the program does not have «significant effect on either drop out or grade advancement for the population as a whole», but «a small negative effect on drop out and a positive effect on grade advancement» could be detected in the poorest areas of the country (Pierri \& Assad, 2014, p. 10). More recently, Edo and Marchionni (2018) describe positive effects of UCA in intra-year drop out rates and primary education completion rates, with an even greater impact on girls aged 12-17, while less encouraging results on the same subject can be found in D'Elía \& Navarro (2013). Garganta et al. (2016) found that UCA may be related to a $2 \%$ increase of fertility rates in potential beneficiaries, though the program has not demographic objectives - at least explicitly. All of these studies focus on efficacy of UCA as an instrument.

Here I propose a different analysis. I examine UCA from a human rights and constitutional rights perspective. Beyond the alleged positive effects of the UCA program or its social legitimacy, fiscal sustainability, or political feasibility, is it consistent with human and constitutional rights granted by Argentinian law?

\section{HuMAN RIGHTS QUESTIONS, CONSTITUTIONAL PROBLEMS}

In Argentina's legal system, human rights questions are also constitutional questions. Most of central human rights international covenants have constitutional rank. Any clause included in these covenants have the highest legal value as domestic law. In 1994, a broad constitutional reform extended the range of human rights through two mechanisms. First, the reform added some rights and guarantees in the Constitution's text, such as consumers' rights (Argentinian Constitution, art. 42), or the right to a healthy environment (art. 41). Another clause orders Congress to keep the entire public education system tuition-free (art. 75.19). 
A second, innovative mechanism was used. The 1994 Convention endowed nine human rights treaties with constitutional rank7 (Koven Levit, 1999), in addition to Argentina's commitment at the international level. The language from international human rights law has to be harmonized with the rest of the Constitution since all these elements share an equal rank (Gelli, 2005, p. 716; Morgan-Foster, 2003, pp. 591-594; Lo Prete, 2009, pp. 680682). The Constitution and the relevant international human rights treaties form what Argentinian law scholars label as «(federal) constitutional block» (Bidart Campos, 2000), a defined set of legal instruments endowed with the highest domestic rank.

The list of social rights has greatly expanded as a result of the 1994 reform. The most relevant treaty in this area, of course, is the International Covenant on Economic, Social and Cultural Rights (ICESCR), monitored by the Geneva-based UN Committee on Economic, Social and Cultural Rights (CESCR). The Covenant becomes even more relevant after 2013, when its Optional Protocol came into effect. Under this Protocol, individual claims may be filed before the CESCR against Argentina, as a State party to both the Covenant and its Optional Protocol ${ }^{8}$.

On the other hand, if any governmental action or omission contradicts these human rights treaties, it is also unconstitutional. Not only international accountability is at stake: actions or omissions can be challenged before domestic courts. Art. 43 of Argentina's Constitution institutes a quick relief action, the amparo action (Rivera-Pérez, 2012, pp. 198-203; Jiménez, 2015; Sagüés, 1999, v. 1, pp. 301-310). Any person can file a petition against any violation of her or his rights; courts can subject any involved statute to constitutional review (Hernández, 2010, pp. 910-911) and, as a result, strike it down and make it inapplicable to the case ${ }^{9}$. Constitutional-rank social

7 Argentinian Constitution, art. 75.22. The same provision includes a Congressional procedure for the removal of these treaties from the constitutional framework, and for the incorporation of new human rights treaties. Both operations require supermajority votes in both houses of Congress.

${ }^{8}$ Argentina ratified the Optional Protocol in 2011; see Law 26.663.

${ }^{9}$ See Argentinian Constitution, art. 43 that provides that:

«[a]ny person shall file a prompt and summary proceeding regarding constitutional guarantees, provided there is no other legal remedy, against any act or omission of the public authorities or individuals which currently or imminently may damage, limit, modify or threaten rights and guarantees recognized by this Constitution, treaties or laws, with open arbitrariness or illegality. In such case, the judge may declare that the act or omission is based on an unconstitutional rule».

For a general review of amparo actions in Latin America, see Brewer-Carías, 2007, and Orrego Hoyos, 2013. 
rights in Argentina also include those espoused in art. 14 bis, a 60-year-old clause. This three-paragraph article, adopted through the 1957 constitutional reform, enumerates workers' rights, union rights and social security guarantees ${ }^{10}$.

Inconsistency between social rights and social policies open the way for individual and collective claims before domestic and international fora. UN Special Rapporteur on Extreme Poverty and Human Rights (2012) has explicitly affirmed that eradication of extreme poverty is a legal obligation under international human rights law-not only a moral duty. Poverty implies deprivation of human rights (CESCR, 2001), turning a social ill into a constitutional question. In the following sections, I intend to make a human rights (and constitutional) assessment of certain aspects of UCA as a legal scheme. I do not focus on its effects but on its design features. In particular, I turn to the conditions required to children for accessing the right to social security, in order to define if such conditions are consistent with Argentina's constitutional and human rights framework.

\section{CONDITIONED RIGHTS}

CCT programs require people to fulfill a certain set of conditions to enjoy a right. The UCA program regulates access to childen's constitutional right to social security, granted in art. 26 of the CRC, art. 9 of the ICESCR and also in art. 14 bis of Argentina's Constitution ${ }^{11}$.

Such a scheme brings to mind more general questions. Can States require specific actions from a person in order to fulfill their own human rights obligations? Should any right be subject to conditions? Nothing in the covenants seems to favor conditioned access to human rights. To the contrary, every right is granted to "everyone", with no references to any condition. Some specific qualifications appear in a few articles. For example, art. 13 of the ICESCR recognizes the right to higher education including a reference to "capacity", which may be construed as a condition to access. In Argentina, another constitutional-rank instrument, the 1948 American Declaration of the Rights and Duties of Man, includes both rights and obligations (Gelli, 2005, p. 400). Yet these duties are not conditions to enjoy rights. Even under this American Declaration, a person does not have

\footnotetext{
${ }^{10}$ Art. 14 bis grants the workers' right to «protection against arbitrary dismissal», «equal pay for equal work», «participation in the profits of enterprises, with control of production and collaboration in the management», and the unions' right to strike.

${ }^{11}$ See Argentinian Constitution, art. 14 bis (establishing that «[t] he State shall grant the benefits of social security, which shall be of an integral nature and may not be waived»).
} 
to fulfill his or her duties in order to exercise any of the rights included in the text. For instance, the State cannot require a person to ensure her elderly parents have proper assistance (art. 30) as a condition to enjoy freedom of religion (art. 3). A full answer to the question of conditioned rights is beyond the scope of this article. My analysis, as can be seen below, does not discuss the inclusion of conditions per se. These are taken as a given feature of CCT programs.

The UCA program requires certain actions to parents. They have to show evidence that children have been subject to medical checkups and mandatory vaccinations (Straschnoy, 2016, p. 184). Parents also have to provide school certificates to prove completion of the appropriate academic courses. All of these actions require families to directly and regularly interact with health and educational bureaucracies (Ambort and Straschnoy, 2018), who become empowered to scrutinize who "deserves" benefits (Arcidiácono, 2017, p. 36). Failure to produce required documents leads to cancellation of benefits ${ }^{12}$. For instance, as of February 2016, more than 500,000 children had their benefit suspended (World Bank, 2016, p. 5). Apparently, these requirements aim to ensure cash transfers are properly used to procure health care and education for every child included in the program.

Is this the only way to ensure this objective? Or are there any less restrictive, more reasonable alternatives? This is a constitutional question. Argentina's Constitution, in its art. 28, adopts "reasonableness" as the guiding principle in regulations on rights ${ }^{13}$. In a well-settled interpretation by Argentina's Supreme Court, "reasonable" regulations must bear a proportional relationship to legitimate objectives (Bidart Campos, 1991, p. 407; Sagués, 1999, v. 2, pp. 880-889). They have to be proportionate means, clearly related to the pursued objectives ${ }^{14}$. There must be a causal connection between the regulation and the desired effect (Gelli, 2005, p. 331).

UCA conditions are part of the regulations applied to the right to social security. Are they proportional to the likely objectives, namely, to make sure health care and education are timely provided to children? If a less restrictive alternative can be devised to achieve the same objective, then UCA regulations are unreasonable, disproportionate, and, for that very reason, unconstitutional. Canceling benefits to children whose parents fail to provide the required certificates appears to be an unreasonable response.

\footnotetext{
${ }^{12}$ See Law 24.714, art. 18.k.

${ }^{13}$ Argentinian Constitution, art. 28, reads: "The principles, guarantees and rights recognized in the preceding sections shall not be modified by the laws that regulate their enforcement". ${ }^{14}$ This concept of "reasonableness" was first articulated in "Inchauspe" (1944); see Miller, 1997a, p. 148. For a more recent application of this principle, see "Irízar" (1996), majority vote, parag. 8 .
} 
There are less restrictive alternatives. For instance, a close relative could be appointed in lieu of parents to collect the transfers and to produce the required certificates. This would separate children from the consequences of their parents' inability to fulfill the UCA conditions.

To sum up, a first constitutional question comes to the surface. Benefit cancellation imposes - on its face - a disproportionate burden on children's right to social security. Less restrictive, more gradual alternatives are conceivable in order to achieve the same objective, namely, making sure certain actions are performed to improve a child's welfare. Unreasonable regulations can be challenged on constitutional grounds.

\section{A QUESTION OF EQUALITY}

Now I turn to a different set of questions. The principles at stake here are not only reasonableness but also equality and nondiscrimination.

The right to equal treatment and the principle of "real equality" [igualdad real] can be found in arts. 16 and 75.23 of Argentina's Constitution $^{15}$ (Gelli, 2005, pp. 181-204). The ICESCR, in turn, establishes that «the rights enunciated in the present Covenant will be exercised without discrimination of any kind» (art. 2.2). Similar language is included in arts. 1 and 7 of the Universal Declaration of Human Rights, and in art. 1 of the American Convention on Human Rights, all of them endowed with constitutional rank.

From this perspective, some inequalities become apparent and deserve scrutiny. Conditions established for UCA beneficiaries are different from the ones in the family allowances system. In the following paragraphs, I analyze the differences in required conditions.

\section{VII.1. Maximum income}

As explained before, registered workers are entitled to family allowances if their combined family income is less than 3,000 US dollars (at August 2018 official exchange rate). Not all of them receive the same amount. Workers are classified in different income tiers: higher income implies lower family allowances. The first tier includes workers whose combined family income is below 875 US dollars. This tier receives the highest family allowances — which equals the UCA, as previously described.

\footnotetext{
15 Argentinian Constitution, art. 16, establishes that all inhabitants are «equal before the law", and that equality "is the basis of taxation and public burdens». After 1994, art. 75.23 enables Congress «to legislate and to promote positive measures guaranteeing true equal opportunities and treatment».
} 
Here is the first difference in treatment: in order to be eligible for UCA, informal workers have to earn less than the minimum wage ${ }^{16}$, set in AR $\$ 10,700$ (roughly 380 US dollars) ${ }^{17}$. In other words, upper limits are different for registered and unregistered employees. An unregistered worker with a wage between 380 and 875 US dollars is excluded from the UCA system. Yet a registered employee with the same wage has a right to receive full family allowances for his or her children.

This difference in treatment appears to be unjustified. Informality is taken as a reason to exclude workers from a social right. Yet lack of registration should not harm the workers since their own labor rights are being affected (for instance, the rights granted in ICESCR, arts. 6 and 7). Quite to the contrary, sanctions should be imposed on employers who skip legal obligations in labor relationships.

Children of some registered workers (those included in the lowestincome tier) receive a benefit which is denied to children whose parents are informal workers with the same income. This difference contradicts the right to equal treatment. It needs to be justified with precise arguments to prove it reasonable, that is, proportional to a specific and legitimate governmental objective. A possible objective under a CCT program would be to reduce "leakage", the percentage of beneficiaries who are not poor (Stampini \& Tornarolli, 2012; Ravallion, 2016). It would be difficult to accept such an argument because both groups of workers have the same income- they only differ in formality. Yet at the same time, the Government would have to prove less restrictive alternatives are not available. In any event, nothing in the creation Decree offers an explanation that could be reviewed in light of the reasonableness principle.

\section{VII.2. Nationality}

Registered workers receive family allowances for every child under 18 years old who is single and lives in Argentina. The UCA system, by contrast, includes an additional requirement: the child must be Argentinian. To be eligible, foreign-born children must have been legal residents at least for the past 3 years ${ }^{18}$. Again, UCA beneficiaries are subject to a different set of conditions, not established for formal employees. Informality becomes the source of an unequal treatment-namely, a more restrictive access threshold.

\footnotetext{
${ }^{16}$ See Decree 1602/2009, art. 2.

17 This figure is in force since September $1^{\text {st }}, 2018$ through November $30^{\text {th }}, 2018$. See Resolution 3/2018 of the National Council on Employment, Productivity and the Minimum Wage (Spanish: Consejo Nacional del Empleo, la Productividad y el Salario Mínimo, Vital y Móvil), issued on August ${ }^{\text {th }}, 2018$.

${ }^{18}$ See Decree 1602/2009, art. 6.
} 
Nationality-related conditions raise specific constitutional questions. Argentina's Constitution explicitly grants equal civil rights for foreigners. As part of an immigration-based project (Miller, 1997, p. 1503), the 1853 Constitution included special provisions to benefit people from other countries who settle in Argentina (Hines, 2010, p. 476). First, as a general rule, constitutional rights are granted to "inhabitants", not only citizens, according to art. 14 of Argentinian Constitution (Bidart Campos, 2000, pp. 754, 762, 770; Sagüés, 1999, v. 2, pp. 302-304; Gelli. 2005, p. 75). Art. 20, in particular, establishes: «Foreigners enjoy within the territory of the Nation all the civil rights of citizens (...)». Argentina's Supreme Court has adopted in the past few decades a strict scrutiny standard for reviewing statutes that appear to discriminate against foreigners ${ }^{19}$.

Only reasonable regulations would be admissible under art. 28. Once again, the UCA creation decree does not include arguments to support this distinction between Argentinian and non-Argentinian children. There is no mention of governmental objectives that could be used to evaluate the proportionality of this distinction in order to assess its reasonableness.

A possible argument could be found in the ICESCR itself. Its art. 2.3 includes a special provision: «Developing countries, with due regard to human rights and their national economy, may determine to what extent they would guarantee the economic rights recognized in the present Covenant to non-nationals» (emphasis added). For the sake of the argument, I will consider here that cash transfer programs could be included among "economic rights", in spite of being part of the social security system (arguably related to a "social right"). Yet even in that case the clause cannot justify, under Argentinian law, the nationality-based distinction in the UCA program. First, art. 14 bis grants social security benefits without any reference to citizenship or national origin as eligibility criteria. In addition to that, the CRC, also endowed with constitutional rank, not only grants children the right to social security (art. 26), but it also prohibits any discrimination based on national origin (art. 2). Taking Argentina's domestic constitutional law as a set of instruments of the same rank (the so-called "constitutional block"), under lex specialis principle specific clauses prevail over more general ones (Barbosa Pinto, 2003, p. 178). The specific clause on social security (art. 14 bis) and the group-specific treaty (CRC) prevail over the more general clause included in the ICESCR.

\footnotetext{
${ }^{19}$ See, for instance, "Repetto" (1986) (holding unconstitutional a resolution that required Argentinian nationality to be a teacher at private schools) and "Calvo y Pessini" (1998) (striking down the same nationality requirement to be part of a public hospital staff). See also Hines, 2010, pp. 477-478.
} 
Under international law, the nationality condition becomes even less justifiable. The ICESCR establishes an important rule:

«No restriction upon or derogation from any of the fundamental human rights recognized or existing in any country in virtue of law, conventions, regulations or custom shall be admitted on the pretext that the present Covenant does not recognize such rights or that it recognizes them to a lesser extent» (art. 5.2).

From an international law perspective, the Covenant and the Constitution are not part of a single "block" (as Argentinian legal scholars describe it from a local standpoint), but separate instruments from different legal orders. When domestic law (for instance, the Constitution) has a more inclusive formulation of a certain right, this internal provision must prevail according to art. 5.2 of the ICESCR. In art. 20, Argentinian Constitution sets up a full-equality principle for foreigners. The exception included in art. 2.3 of the Covenant must yield.

The CESCR has criticized the UCA regulation on foreign-born children. In its 2011 Concluding Observations on Argentina, the Committee expressed its concern «that requirements to receive the universal allowance for children, which is granted by law, in practice exclude certain groups such as migrants and their children from receiving this benefit». Alternative reports by civil society organizations had also raised the question. The Committee calls upon Argentina «to consider adopting all the necessary measures to ensure the unrestricted coverage of the universal allowance for children» (CESCR, 2011, p. 6). The Committee is the Covenant's monitoring body of experts. Its opinion bears also high domestic relevance. Argentina's Supreme Court has defined the Committee as an "authoritative interpreter" of the Covenant ${ }^{20}$. According to a widely supported opinion among Argentina's constitutional scholars, comments and conclusions from international monitoring bodies should inform the local interpretation of treaties (Gelli, 2005, pp. 712-713; Sagüés, 1999, v. 2, pp. 279-280; Quiroga Lavié, 2000, p. 483). In September 2018, Argentina's periodic report on ICESCR implementation will be reviewed by the Committee, leading to a new Concluding Observation.

\section{VII.3. Required documents}

I have briefly described what documents UCA beneficiaries must produce in order to remain included in the system: medical and school certificates $^{21}$. On the other hand, registered workers are not required to

\footnotetext{
${ }^{20}$ See "Q. C." (2012), majority vote, parag. 10.

${ }^{21}$ See Decree 1602/2009, art. 6.
} 
provide these documents as a condition to receive family allowances. Once again, different treatment is established only because of labor informality, which is not the worker's choice, but the employer's.

This different set of conditions also implies a stigma. It expresses an unjustified assumption, namely, that unregistered workers are less likely to take their children to school, or to the hospital to get medical care or mandatory vaccines. Such an assumption would be the only logical reason to require certificates only to informal employees. In her research, Straschnoy (2016, p. 188) reports public authorities often describe conditionalities as instruments to "correct" parental behavior. According to UCA regulation, only informal workers need to be corrected.

The right to equal treatment before the law precludes the State from unduly describing and treating a class of people (unregistered workers, in this case) as less worthy of consideration, or less trustworthy. The legal imposition of specific conditions amounts to a public expression of the State's undue assumption. The UCA decree does not justify it: no empirical or other evidence is offered. Consequently, unjustified differences in treatment amount to discrimination, due to lack of reasonableness. The condition may be subject to constitutional challenge.

\section{VII.4. Number of included children}

Under the UCA system parents receive an allowance for each child up to a maximum of five children ${ }^{22}$. There is no allowance for any additional child. On the other hand, registered workers get an allowance for every child: the family allowances system does not include a ceiling in the number of covered children. If a registered employee has 6 children, he or she gets 6 allowances (approximately 336 US dollars). An informal worker in the same situation gets only 5 allowances ( 280 US dollars). This is a concrete difference in treatment: $20 \%$ less money. It requires a thorough explanation in order to be reasonable, and for that reason, constitutionally admissible. Different treatment also becomes apparent among the unregistered worker's children: the first five children receive an allowance that is denied to the sixth child, the seventh child, and so on.

I sum up the constitutional question as follows. The system treats differently two groups: registered workers and informal workers (and families from both groups). The latter group has a much lower maximum wage limit to be eligible. Children from this group must fulfill specific nationality or legal residence conditions. Unregistered workers have to

\footnotetext{
22 See Decree 1602/2009, art. 5.
} 
produce certificates, while formal workers are not required to do so. Finally, there is a maximum of five children per family that can be covered by the UCA program, while family allowances are delivered to every child in a family with no limits. All of these differences do not arise from practice: they are thoroughly worded in the UCA legal framework. Every element has been planned and included. It is too early to know if these differences will definitely evolve into a two-track social security system, reinforcing the worst traditions of Latin American social segmentation (Valencia Lomelí, 2008, p. 491).

All of these differences can surely be described as a set of regulations on the access to the right to social security. As explained before, the State has to justify them, explaining how these regulations serve a legitimate governmental purpose, with no disproportionate burdens on workers' and children's rights. In other words, the State must show how these differences are "reasonable" under art. 28 of Argentina's Constitution. Yet no suitable explanation is offered in the UCA creation decree: this silence makes it difficult to consider all the system's conditions as a reasonable set of regulations.

A probable, though not explicit, reason for the exisiting regulation is fiscal sustainability. Yet it does not justify disregard for constitutional clauses. In a 2012 landmark decision on the right to housing, Argentina's Supreme Court made clear that resource scarcity per se does not exempt the State from its obligations ${ }^{23}$. This position follows the lines defined by the CESCR in its analysis of art. 2.1 of the ICESCR. In General Comment number 3, the Committee makes clear that «even where the available resources are demonstrably inadequate, the obligation remains for a State party to strive to ensure the widest possible enjoyment of the relevant rights under the prevailing circumstances» (CESCR, 1990). n other words, the Covenant's reference to the availability of resources does not give State parties unrestricted discretionary powers to define to what extent social rights will be honored. Such an interpretation would violate the pacta sunt servanda principle ${ }^{24}$ : States would be signing a Covenant which includes a clause that makes the rest of the Covenant non-binding (Craven, 1995, p. 136). In any event, the UCA creation decree does not include any reference

${ }^{23}$ See “Q. C." (2012), majority vote, parag. 14; see also Justice Petracchi's concurring opinion, parag. 17.

${ }^{24}$ In public international law, it means that States must respect their obligations established by treaty. It is a widely recognized and accepted principle in international law, included in art. 26 of the 1969 Vienna Convention on the Law of Treaties: "Every treaty in force is binding upon the parties to it and must be performed by them in good faith." Argentina ratified the Vienna Convention on December $5^{\text {th }}, 1972$. 
to the availability of resources, nor any other justification based on fiscal considerations.

According to Arcidiácono (2017), the inequalities described above may be "recodified" as "conditioned rights" — while "genuine rights" would only belong to the contributory system. A new administration took office in December 2015. President Mauricio Macri, a multimillionaire engineer backed by a right-of-center coalition supportive of pro-investment policies (Casullo, 2016; Lansberg Rodríguez, 2016; Vommaro, 2017), has not improved the UCA regulation. He has even promoted a regressive measure: Congress approved his proposal to change the applicable adjustment index ${ }^{25}$.

An additional observation: all these differences in treatment were present in the 2011 World Bank loan documents that assessed UCA as a social policy. The institution was completely aware of the unequal treatment established in the system. This is hardly a surprise since the Bank does not evaluate its projects according to human rights standards (Darrow, 2003, pp. 19, 51; Sarfaty, 2009; Ghazi, 2005), such as the right to social security or the equality or non-discrimination principles. The Bank argues human rights are beyond its mission and describes itself as a technical institution with a non-political mandate. Moreover, it does not consider itself bound by international human rights instruments (Ghazi, 2005, pp. 82-83), and does not take into account human rights obligations of borrower countries in assessing or designing policy proposals (Sarfaty, 2009, pp. 647-648).

This highlights the need to rethink the way social policies are designed at the domestic level. A traditional approach identifies existing problems and available resources, in order to devise solutions and proposals based on efficacy, political feasibility, and fiscal sustainability considerations. In this designing process, human rights and other constitutional rights are not included as decisive criteria.

Yet a democratic, constitutional State should not follow this pattern. Social problems, at least to some extent, are also violations of human and constitutional rights (social rights, in this case). Hunger, malnutrition, homelessness, illiteracy, exploitation, and unemployment are not only troubling social situations but also constitutional questions. Any proposal to deal with them must also be consistent with the Constitution.

Policy design should start by identifying the rights at stake-health, education, housing - in order to set the goals and select the instruments to achieve their full realization, or their progressive realization, according to art. 2.1 of the ICESCR. Authorities must make sure every step is consistent with applicable constitutional principles and rights. That is efficacy from a

\footnotetext{
${ }^{25}$ See Law 27.426.
} 
human rights perspective. The "maximum of available resources" (as required by art. 2.1), with due consideration to all rights granted by the State, should be committed to this task: that is fiscal sustainability in this context. Finally, the State should communicate what are its obligations under the ICESCR, offering facts and information to inform and expand a free public debate and an open social dialogue on the policy: that is how political feasibility can be achieved. These are just very general lines on how policy design follows a different path when rights are taken as mandatory guiding lines. This approach makes it more likely that policies will survive any constitutional scrutiny under judicial review.

\section{CONCLUSIONS: POLICY IMPLICATIONS OF CONSTITUTIONAL REVIEW}

1. After 1994 reform, Argentina's constitutional commitment to human rights requires State organs to base their actions and policies on those rights. The rest of constitutional rights are part of the same fundamental framework that defines the limits of policymaking.

2. Social policies, just like any other policy, can be subject to constitutional review. Under that light, the UCA system gives unregistered workers unequal treatment. Only children from this group must fulfill specific nationality or legal residence requirements. Informal workers, in turn, must produce school and medical certificates to receive UCA, while formal workers under family allowances program are not required to do so. Compared to family allowances beneficiaries, informal workers have a much lower maximum wage limit to be eligible. In addition to that, UCA system covers only up to five children per family, while family allowances are paid to every child in registered workers' families, without restrictions.

3. The creation Decree offers no explicit justification that could turn those differences into a reasonable regulation. From a constitutional perspective, unjustified different treatment to UCA-covered families makes judicial challenges possible. Any family with more than five children may file an amparo action to require additional allowances invoking the right to equal treatment. The same argument would be useful for parents of foreignborn children to demand their inclusion in the UCA program. Equality also appears to be a relevant argument for unregistered workers earning more than the minimum wage. If local courts fail to provide relief, international monitoring mechanisms lay ahead. Planned, unjustified differences have no place in Argentina's constitutional framework. 


\section{REFERENCES}

Abouharb, M. R. \& Cingranelli, D. (2007). Human rights and structural adjustment. Cambridge: Cambridge University Press.

Ambort, M. \& Straschnoy, M. (2018). Burocracias escolar y sanitaria, ¿facilitadores u obstaculizadores del acceso a la Asignación Universal por Hijo y la Asignación por Embarazo para la Protección Social? Horizontes Sociológicos, 5, 139-161.

Arcidiácono, P. (2016). Expansion and exclusion in the Universal Child Allowance programme in Argentina. Sur, 13(24), 27-34.

Arcidiácono, P. (2017). Asignación Universal por Hijo. Rupturas y continuidades en el campo de las transferencias de ingresos en la Argentina. Igualdad, autonomía y derechos sociales, $6,11-42$.

Argentinian Supreme Court. Calvo y Pesini, Rocío vs. Córdoba, Provincia de s/ amparo. 24-II-1998. Fallos, 321:194.

Argentinian Supreme Court. Inchauspe Hnos vs. Junta Nacional de Carnes. 1-IX-1944. Fallos, 199:483.

Argentinian Supreme Court. Irízar, José M. vs. Provincia de Misiones. 12-IX-1996. Fallos, 319:1934.

Argentinian Supreme Court. Q. C., S. Y. vs. Gobierno de la Ciudad de Buenos Aires s/ amparo. 24-IV-2012. Fallos, 335:452.

Argentinian Supreme Court. Repetto, María Inés vs. Buenos Aires, Provincia de s/ inconstitucionalidad de normas legales. 8-XI-1988. Fallos, 311:2272.

Arza, C. (2018). Cash transfers for families and children in Argentina, Brazil and Chile: segmented expansion or universal benefits? Journal of International and Comparative Social Policy, 34(1), 58-75. doi:10.1080/21699763.2017.1415218

Barbosa Pinto, M. (2003). Interpretation and conversation. Legal Theory, 9(2), 157-179.

Bertranou, F. \& Maurizio, R. (2012). Semi-conditional cash transfers in the form of familly allowances for children and adolescents in the informal economy in Argentina. International Social Security Review, 65(1), 53-72. doi:10.1111/j.1468246X.2011.01419.x

Bidart Campos, G. J. (1991). Teoría general de los derechos humanos. Buenos Aires: Astrea.

Bidart Campos, G. J. (2000). Tratado elemental del derecho constitucional argentino (vol. I-A). Buenos Aires: Ediar.

Brewer-Carías, A. (2007). Some aspects of the "amparo" proceeding in Latin America as a constitutional judicial mean specifically established for the protection of human rights. International \& Comparative Law Colloquium Papers, University of Maryland. At http://digitalcommons.law.umaryland.edu/iclc_papers/2/ (accessed 21-XI-2018). 
Casullo, M. E. (2016). Argentina turns right, again. NACLA Report on the Americas, 48(4), 361-366. doi:10.1080/10714839.2016.1258279

Ceballos, M. \& Lautier, B. (2013). Les CCTP en Amérique Latine: Entre modélisation internationale et conjonctures politiques nationales. Revue Tiers Monde, 214, 219-245. doi:10.3917/rtm.214.0219

CESCR (1990). General Comment No. 3. The nature of State parties obligations. Available at: https://tbinternet.ohchr.org/Treaties/CESCR/Shared\%20Documents/1_Glob al/INT_CESCR_GEC_4758_E.doc (accesed 22-XI-2018),

CESCR (2001). Poverty and the International Covenant on Economic, Social and Cultural Rights. E/C.12/2001/10.

CESCR (2011): "Concluding observations of the Committee on Economic, Social and Cultural Rights - Argentina", E/C.12/ARG/CO/3.

Conklin, M. \& Davidson, D. (1986). The I.M.F. and economic and social human rights: a case study of Argentina, 1958-1985. Human Rights Quarterly, 8(2), 227-269.

Constitution [Constitución de la Nación Argentina]. Argentina's Ministry of Justice official English translation, available at: http://www.biblioteca.jus.gov.ar/argentinaconstitution.pdf (accessed 8-VIII-2018).

Craven, M. C. R. (1995). The International Covenant on Economic, Social, and Cultural Rights. A perspective on its development. Oxford: Clarendon Press.

D’Elía, V. V. \& Navarro, A. (2013). Universal Child Allowance and school delay in Argentina. Revista de Análisis Económico, 28(2), 63-90. doi:10.4067/S071888702013000200003

Darrow, M. (2003). Between Light and Shadow: The World Bank, the International Monetary Fund and International Human Rights Law. Portland: Hart Publishing.

Fiszbein, A., Schady, N., Ferreira, F., Grosh, M., Kelleher, N., Olinto, P. \& Skoufias, E. (2009). Conditional cash transfers: reducing present and future poverty. Washington D.C.: World Bank. doi:10.1596/978-0-8213-7352-1

Garganta, S., Gasparini, L., Marchionni, M. \& Tappata, M. (2016). The effect of cash transfers on fertility: evidence for Argentina. Population Research and Policy Review, 36(1), 1-24. doi:10.1007/s11113-016-9417-x

Gelli, M. A. (2005). Constitución de la Nación Argentina. Comentada y concordada (3rd edition). Buenos Aires: La Ley.

Ghazi, B. (2005). The IMF, the World Bank Group and the question of human rights. London: Transnational Publishers.

Ham, A. (2014). The impact of conditional cash transfers on educational inequality of opportunity. Latin American Research Review, 49(3), 153-175. doi:10.1353/lar.2014.0049

Hernández, A. M. (2010). Judicial Federalism and the Protection of Fundamental Rights in Argentina. Rutgers Law Journal, 41, 907-930. 
Hines, B. (2010). The right to migrate as a human right: the current Argentine immigration law. Cornell International Law Journal, 43, 471-511.

Jiménez, E. (2015). El derecho de toda persona a interponer acción expedita y rápida en defensa de sus derechos constitucionales. Análisis del artículo 43 de la Constitución Nacional. In M. Bernal, C. Pizzolo \& A. Rossetti (eds.). ;Que veinte años no es nada! Un análisis crítico a veinte años de la reforma constitucional de 1994 en Argentina (327-353). Buenos Aires: Eudeba.

Kanbur, R. \& Vines, D. (2000). The World Bank and poverty reduction: past, present and future. In C. Gilbert \& D. Vines (eds.). The World Bank. Structure and policies (87-107). Cambridge: Cambridge University Press.

Koven Levit, J. (1999). The Constitutionalization of Human Rights in Argentina: Problem or Promise? Columbia Journal of Transnational Law, 37, 281-351.

Lansberg Rodríguez, D. (2016). Life after Populism: Reforms in the Wake of the Receding Pink Tide. Georgetown Journal of International Affairs, 17(2), 56-65.

Lavinas, L. (2015). Latin America: Anti-poverty schemes instead of social protection. Contemporary Readings in Law and Social Justice, 7(1), 112-171.

Lo Prete, O. (2009). The protection of Religious Freedom by the National Constitution and by Human Rights Treaties in the Republic of Argentina. Brigham Young University Law Review, 2009, 673-695.

Lo Vuolo, R. (2012). The "Allowance per Child" program of Argentina and income cash transfer programs. The Perspective of the World Review, 4(2), 153-171.

Losada Revol, I. (2017). The Ministry of Foreign Affairs case: A ruling with unforeseen consequences in the enforcement of human rights in Argentina. Georgetown Journal of International Law, 49, 461-500.

Miller, J. M. (1997). The authority of a foreign talisman: A study of US constitutional practice as authority in nineteenth century Argentina and the Argentine elite's leap of faith. American University Law Review, 46, 1483-1572.

Miller, J. M. (1997a). Judicial review and constitutional stability: a sociology of the US model and its collapse in Argentina. Hastings International and Comparative Law Review, 21, 77-176.

Ministerio de Educación (2011). Análisis y evaluación de los aspectos educativos de la Asignación Universal por Hijo (AUH). Buenos Aires: Ministerio de Educación de la Nación. Available at https://www.argentina.gob.ar/sites/default/files/ analisis_y_evaluacion_de_los_aspectos_educativos_de_la_auh.pdf (accesed 22XI-2018)

Morais de Sá e Silva. M. (2017). Poverty reduction, education, and the global diffusion of conditional cash transfers. New York: Palgrave Macmillan. doi:10.1007/978-3319-53094-9.

Morgan-Foster, Jason (2003). The relationship of IMF structural adjustment programs to economic, social, and cultural rights: the Argentine case revisited. Michigan Journal of International Law, 24, 577-646. 
Morissens, A. (2018). The role of universal and targeted family benefits in reducing poverty in single-parent families in different employment situations. In R. Nieuwenhuis \& L. C. Maldonado (eds.). The triple bind of single-parent families. Resources, employment and policies to improve well-being (359-381). Bristol: Policy Press at University of Bristol. doi:10.2307/j.ctt2204rvq.7

National Council on Employment. Resolution 3/2018, Productivity and the Minimum Wage (Spanish: Resolución 3/2018, Productividad y el Salario Mínimo, Vital y Móvil), issued on 8-VIII-2018.

Orrego Hoyos, G. (2013). The amparo context in Latin American jurisdiction: an approach to an empowering action. Globalex. Available at http://www.nyulawglobal.org /globalex/Amparo.htm (accesed 22-XI-2018).

Pautassi, L. (2017). Políticas sociales para la infancia en América Latina. Un balance urgente. Igualdad, autonomía y derechos sociales, 6, 45-91.

Pierri, G. \& Assaad, R. (2014). The impact of Argentina's Universal Child Allowance cash transfer program on children's education outcomes. At http://paa2015.princeton.edu/papers/150844 (accesed 22-XI-2018).

Pribble, J. (2013). Welfare and party politics in Latin America. Cambridge University Press: New York. doi:10.1017/CBO9781139343299

Quiroga Lavié, H. (2000). Constitución de la Nación Argentina. Comentada (3rd ed.). Buenos Aires: Zavalía.

Rabinovich, L. \& Diepeveen, S. (2015). The design of conditional cash transfers: Experiences from Argentina's Universal Child Allowance. Development Policy Review, 33(5), 637-652. doi:10.1111/dpr.12127

Ravallion, M. (2016). The World Bank: why it is still needed and why it still disappoints. Journal of Economic Perspectives, 30(1), 77-94.

Ribe, H., Carvalho, S., Liebenthal, R., Nicholas, P. \& Zucherman, E. (1990). How adjustment programs can help the poor. The World Bank's experience. World Bank Discussion Papers, 71. Washington D.C.: World Bank.

Rivera-Pérez, W. (2012). What the Constitution got to do with it: expanding the scope of constitutional rights into the private sphere. Creighton International and Comparative Law Journal, 3(1), 189-214.

Sagüés, N. P. (1999). Elementos de Derecho Constitucional (vols. 1 and 2). Buenos Aires: Astrea.

Skocpol, T. (1991). "Universal appeal: politically viable policies to combat poverty". The Brookings Review, 9, 29-33.

Stampini, M. \& Tornarolli, L. (2012). The growth of Conditional Cash Transfers in Latin America and the Caribbean: did they go too far?, Policy Brief No. IDB-PB-185. Washington D.C.: Inter-American Development Bank. Available at http://idbdocs.iadb.org/wsdocs/getdocument.aspx?docnum=37306295 (accessed 22-XI-2018).

Straschnoy, M. (2016). "Usos y razones de las condicionalidades en la política social argentina". In L. Pautassi \& G. Gamallo (eds.). El bienestar en brechas. Las 
políticas sociales en la Argentina de la posconvertibilidad (167-198). Buenos Aires: Biblos.

UN Special Rapporteur on Extreme Poverty and Human Rights (2012). Final draft of the guiding principles on extreme poverty and human rights, submitted by the Special Rapporteur on extreme poverty and human rights, Magdalena Sepúlveda Carmona. A/HRC/21/39. Available at https://www.ohchr.org/Documents/HRB odies/HRCouncil/RegularSession/Session21/A-HRC-21-39_en.pdf (accesed 22XI-2018).

Valencia Lomelí, E. (2008). Conditional Cash Transfers in Latin America: an assessment of their contributions and limitations. Annual Review of Sociology, 34, 475-499.

Vommaro, G. (2017). La larga marcha de Cambiemos. La construcción silenciosa de un proyecto de poder. Buenos Aires: Siglo XXI.

World Bank (2009). Report No 47874-AR (Project appraisal document on a proposed loan in the amount of US\$450 million to the Argentine Republic for a basic protection project), Washington D.C.: World Bank.

World Bank (2011). Report No 59201-AR (Argentina - Basic Protection Project additional financing). Washington D.C.: World Bank.

World Bank (2011b): "Argentina/World Bank: Social Protection Programs Expand to Benefit Children”, press release No:2011/362/LAC. 10-III-2011. Available at: http://go.worldbank.org/EHZC3EK3Z0 (accessed 22-XI-2018).

World Bank (2016). Report N PAD1853 (Project appraisal document on a proposed loan in the amount of US\$600 million to the Argentine Republic for a children and youth protection project). Washington D.C.: World Bank. 